(C) Tikhilov R.M., Shubnyakov M.I., Boyarov A.A., Riahi A., Shubnyakov I.I., 2020

DOI 10.18019/1028-4427-2020-26-2-238-243

\title{
The impact of the acetabular component position on the rate of the polyethylene liner wear and periprosthetic osteolysis: a clinical case
}

\author{
R.M. Tikhilov, M.I. Shubnyakov, A.A. Boyarov, A. Riahi, I.I. Shubnyakov
}

Vreden National Medical Research Center of Traumatology and Orthopedics, Saint Petersburg, Russian Federation

\begin{abstract}
Introduction Osteolysis is a common problem in the long-term outcome after total hip arthroplasty, since the wear of a polyethylene liner is an inevitable process. However, its pace depends on many factors and not all of them have been proven. In particular, many studies do not find a connection between the wear rate of the liner and the position of the acetabular component. The purpose of this publication is to demonstrate the importance of correct acetabular component positioning. Methods A clinical case of bilateral total hip arthroplasty with follow-ups after 17 and 19 years is presented. The patient was operated being 31 and 33 years old, respectively, by one surgeon. The same type of the acetabular component was installed with the same type of polyethylene and friction pair diameter. It eliminates implant or surgical approach factors and patient characteristics. The position of the implant components is then remains the most important factor. For analysis, there were radiographs before the operation, at different times after it, CT data and intraoperative photos during the revision surgery. Results At the time of the last examination, there were minor manifestations of retroacetabular osteolysis that were better seen in CT and were more pronounced on the right. CT radiometry data on the angles of inclination of the acetabular components were $50.6^{\circ}$ and $46.7^{\circ}$ on the right and left, respectively, and the anversion was $40.3^{\circ}$ and $25.4^{\circ}$. Revision of the right total hip arthroplasty was performed and it was found that the liner wear extended till the metal layer. Given good fixation of the cup, only the liner was exchanged and osteolytic cavities were filled with allogenic bone chips. Discussion The case can be considered a very good result of primary arthroplasty as revision surgery in this young patient was performed only after 17 years. However, in the contralateral joint the implant with the same pair of friction has survived for 19 years and at the moment it is early to decide on its revision. In our opinion, this case is an excellent illustration of the importance of the correct positioning of implant components.
\end{abstract}

Keywords: total hip arthroplasty, revision total hip arthroplasty, periprosthetic osteolysis, cup malposition, liner exchange

\section{INTRODUCTION}

Primary total arthroplasty (PTA) is one of the most effective and widespread methods of treating terminal stages of hip joint (HJ) diseases of any etiology resulting in pain relieve and improvement of the functions of the entire musculoskeletal system [1, 2]. According to the data of numerous studies and annual reports of arthroplasty registers, the main reason for revisions of an artificial hip joint in the long term is aseptic loosening of the components due to osteolysis caused by wear debris of the implant friction pair [2-7]. The long-term effectiveness of joint replacement depends on many mutually affecting factors, the combination of which enhances the possible negative consequences of the implant functioning. The factors are associated with the implant (material and design), the patient (age, motor activity, body weight, etc.) and the surgeon (surgical technique and correct positioning of components) [8-10].

Identification of the direct cause that led to accelerated wear of the friction unit and the development of adverse reactions to the implant is always a difficult task, since it is extremely difficult to homogenize the group for some reason and eliminate the effect of other possible factors (confounders) [11]. Therefore, this clinical observation is of a considerable interest from the point of view of understanding the importance of the correct positioning of the acetabular component for the optimal functioning of the implant friction unit. We did not find such a vivid demonstration of the dependence of wear on the position of the cup in the available literature.

\section{MATERIAL AND METHODS}

Case history The patient felt pain in the area of both hip joints from the age of 20 and was treated conservatively for a long time. Due to increasing pain caused by protrusive arthritis and a decrease in the range of motion, PTA of the left and right hip joints was performed at the age of 31 and 33 years, respectively.

Tikhilov R.M., Shubnyakov M.I., Boyarov A.A., Riahi A., Shubnyakov I.I. The impact of the acetabular component position on the rate of the polyethylene liner wear and periprosthetic osteolysis: a clinical case. Genij Ortopedii, 2020, vol. 26, no 2, pp. $238-243$. DOI 10.18019/1028-4427-2020-26-2-238-243 
The postoperative period in both stances was uneventful; no complications in the surgical wound and implant occurred. The patient was fully satisfied with the results of the operations, moved without restrictions and additional supports. Periodic radiographic examinations did not reveal functional disorders of the joints, and there were no radiological signs of osteolysis. However, there was a gradual increase in the decentration of the implant head, a sign of wear of the polyethylene liner, more pronounced in the right $\mathrm{HJ}$ (Fig. 2). In the last year, the liner wear in the right $\mathrm{HJ}$ reached a critical level, but osteolysis in both joints was minimally expressed. However, minor radiological changes in the bone of the right joint were associated with severe pain, possibly due to synovitis caused by excessive release of wear particles (Fig. 3).

Physical examination data were: the patient's height was $165 \mathrm{~cm}$, weight $110 \mathrm{~kg}$ (BMI $40.4 \mathrm{~kg} / \mathrm{m}^{2}$ ), the Trendelenburg symptom was negative, active movements were moderately limited in the right $\mathrm{HJ}$ due to pain, passive movements without significant

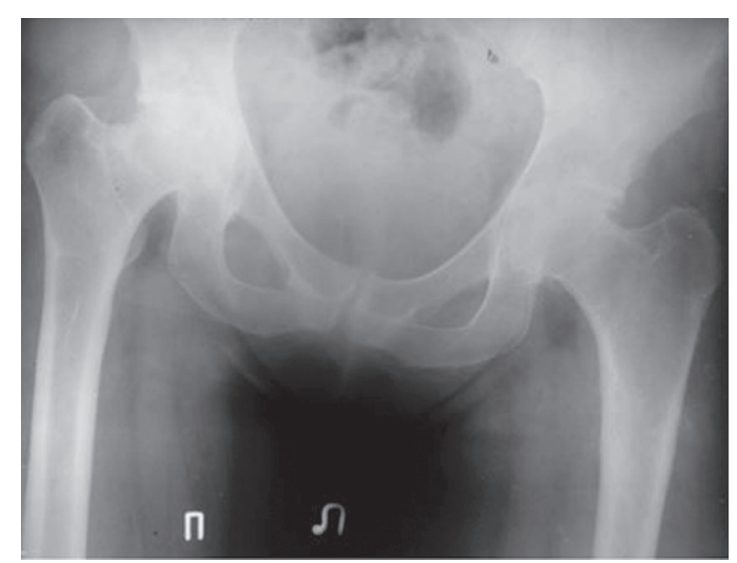

restrictions on both sides (flexion/extension $80^{\circ} / 180^{\circ}$, external/internal rotation $45^{\circ} / 30^{\circ}$, abduction/adduction $50^{\circ} / 20^{\circ}$ ).

Due to persistent pain and obvious signs of significant abrasion of the polyethylene liner, revision arthroplasty was performed. During the revision procedure, metallosis was discovered developed due to the contact of the head with the metal sheath, destruction of the edge of the polyethylene liner and the metal locking ring (Fig. 4).

As the cup was stable, it was decided to install a liner made of highly cross-linked polyethylene on bone cement. Excessive tilt and anteversion were corrected while installing the liner. The osteolytic cavity along the upper edge of the acetabular component was filled with allogenic bone chips (Fig. 5). The postoperative period was uneventful; pain stopped within two weeks; local and general complications were not noted. Three months later, the patient felt fully recovered, did not use additional supports and ambulated well.
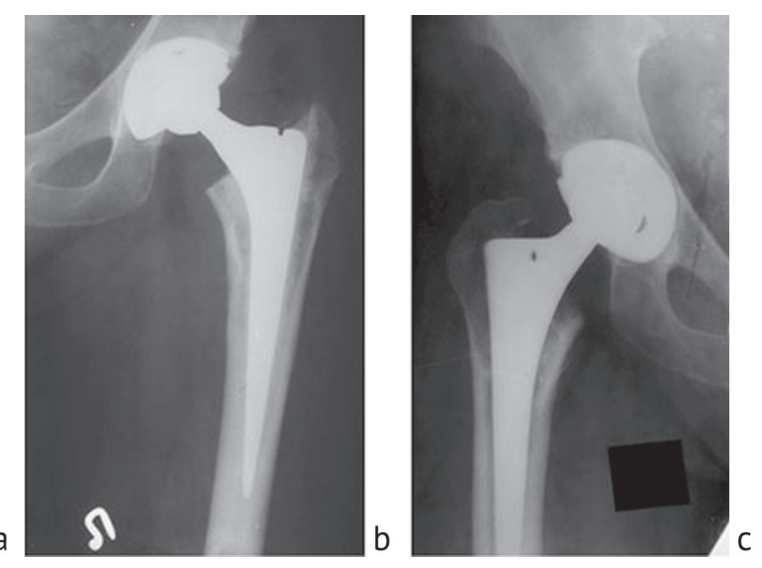

Fig. 1 Bilateral protrusive arthritis of the hip joints $(\boldsymbol{a})$; (b) left hip joint arthroplasty at the age of 31 years (hybrid fixation: Trilogy cup and ultra-high molecular weight polyethylene liner, CPT stem; stainless steel head, $28 \mathrm{~mm}$ in diameter, Zimmer, Warsaw, IN, USA); (c) right hip joint arthroplasty at the age of 33 years (cementless fixation: Trilogy cup, ultra-high molecular weight polyethylene liner, VerSys ET stem; comochromic head, $28 \mathrm{~mm}$ in diameter, Zimmer, Warsaw, IN, USA)
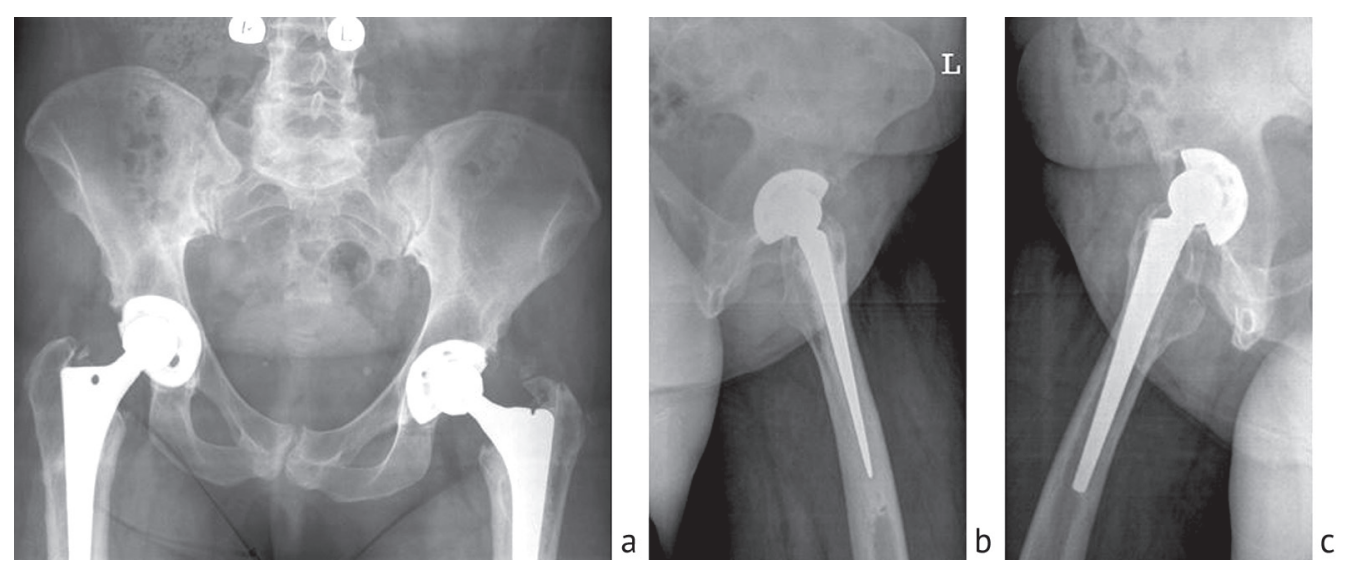

Fig. 2 Frontal X-ray of the pelvis and lateral radiographs of the hip joint 8 years after arthroplasty on the left side $(\boldsymbol{a}, \boldsymbol{b})$ and 6 years after arthroplasty on the right $(\boldsymbol{a}, \boldsymbol{c})$. Moderate malposition of the acetabular component on the right (excessive angle of inclination and anteversion) 

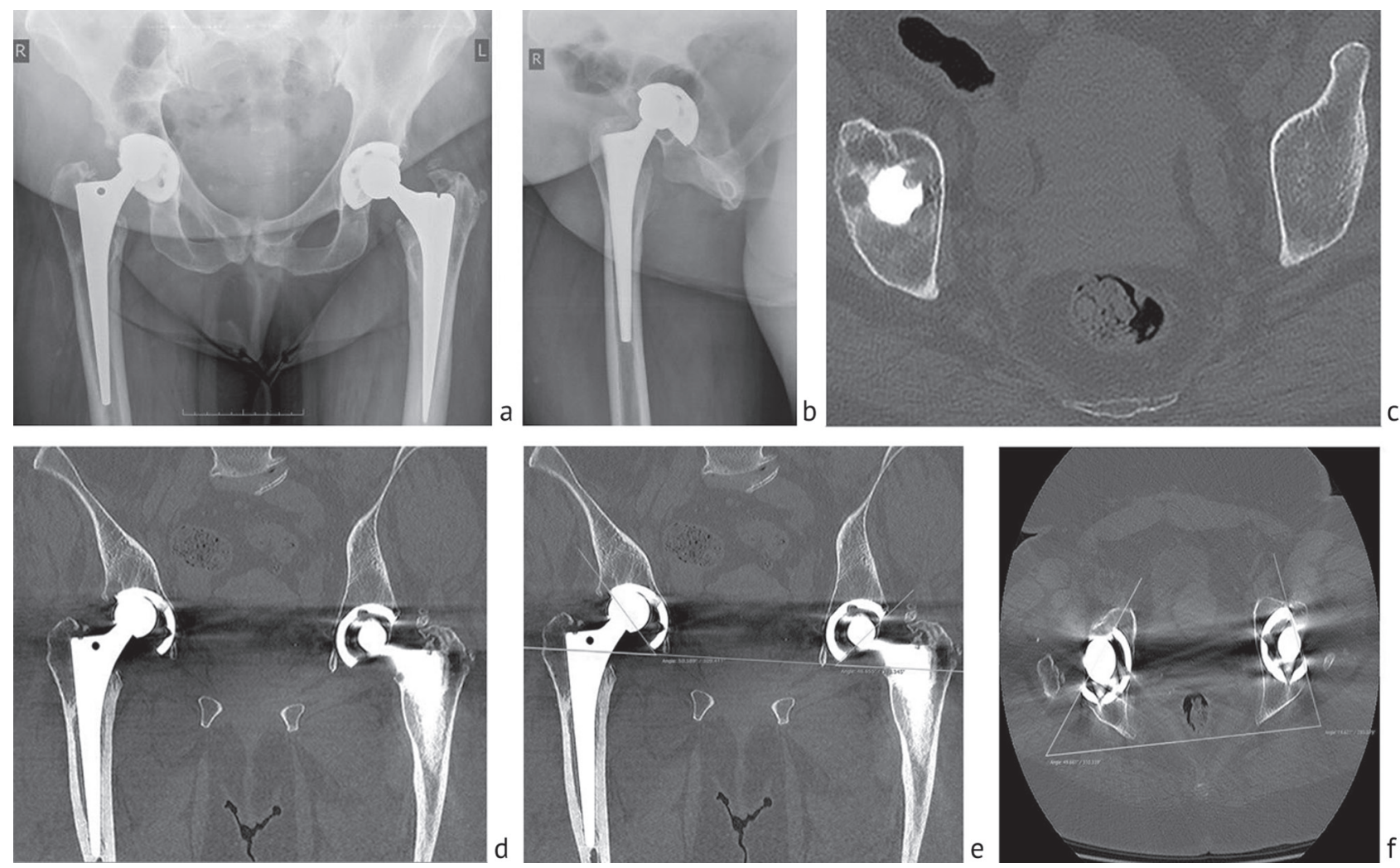

Fig. 3 Radiographs and CT scans after arthroplasty of both hip joints after 19 years on the left side and 17 years on the right one. A critical level of polyethylene wear in the right hip joint is noted on the frontal radiograph of the pelvis $(\boldsymbol{a})$ and the lateral view of the right hip joint $(\boldsymbol{b})$. There are minor manifestations of retroacetabular osteolysis, which are better differentiated by CT and more pronounced on the right $(\boldsymbol{c}, \boldsymbol{d})$. The measurement according to CT data: the angles of inclination of the acetabular components are $50.6^{\circ}$ and $46.7^{\circ}$ on the right and left, respectively, and anteversion is $40.3^{\circ}$ and $25.4^{\circ}(\boldsymbol{e})$, respectively
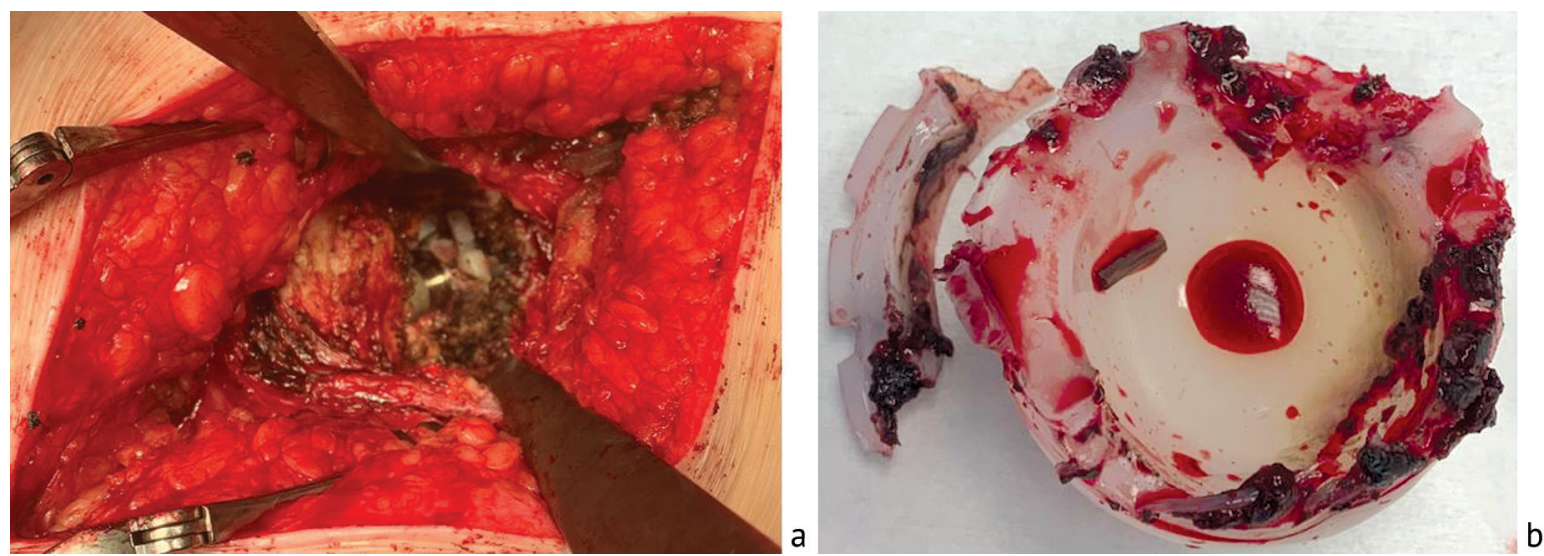

Fig. 4 Metallosis of periarticular tissues and breach of the polyethylene liner $(\boldsymbol{a})$, a destroyed liner and a fragment of a broken metal locking ring inside the liner $(\boldsymbol{b})$
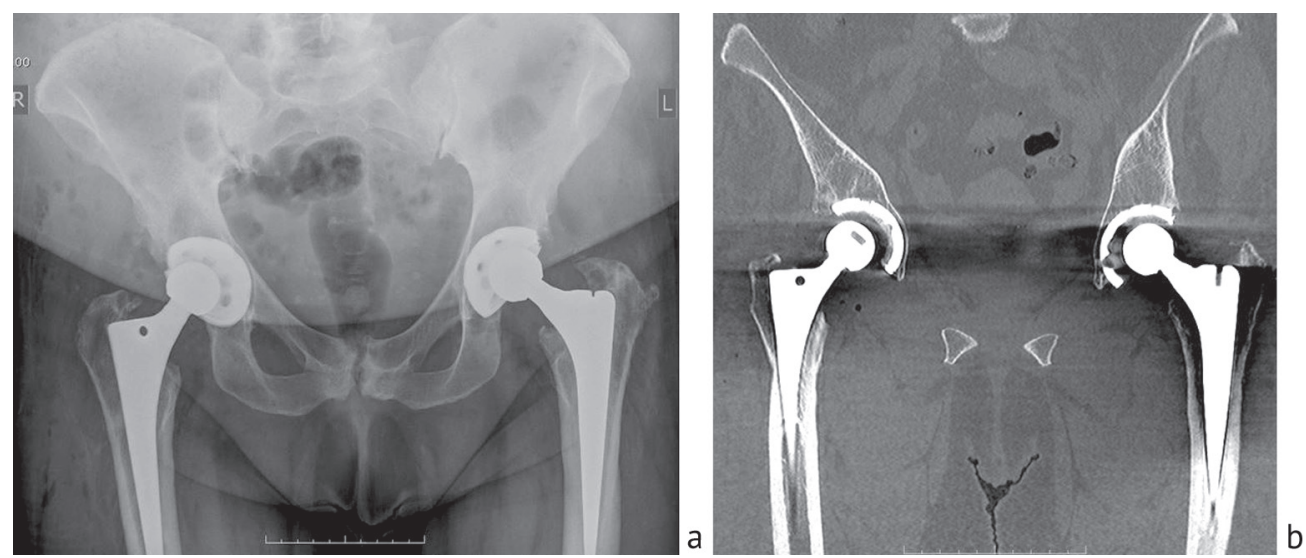

Fig. 5 AP X-ray of the pelvis $(\boldsymbol{a})$ and CT scan after revision arthroplasty $(\boldsymbol{b})$. The head of the right hip joint is located somewhat eccentric relative to the metal part of the acetabular component due to the adjusted position of the liner. The cyst in the region of the upper edge of the acetabular component is partially filled with allogenic bone 


\section{RESULT AND DISCUSSION}

Periacetabular osteolysis is a fairly common cause of revision in the long term after replacement of the hip joint $[3,12,13]$. In particular, according to our register, liner wear and periprosthetic osteolysis are the cause of $17.9 \%$ of revisions 10 years after the primary $\mathrm{HJ}$ arthroplasty, while in $93 \%$ of such revisions only the replacement of modular components and sometimes osteolytic cavity plasty are performed [3].

The duration of the normal functioning of the artificial joint implant varies significantly depending on the conditions of its use. Excessive polyethylene wear can potentially be associated with increased load on friction surfaces, compromised friction conditions, and low wear resistance of the materials $[2,14,15]$.

According to many researchers, the most significant factors affecting the rate of wear are the properties of the friction surfaces (friction coefficient and abrasion resistance) and a high level of patient's activity [9, 11, 16, 17, 18]. Ceramic-on-ceramic friction pairs exhibit the lowest tribological characteristics, which demonstrate the lowest level of wear of the contacting surfaces and the lowest revision rate due to osteolysis and aseptic loosening [17, 19, 20, 21, 22]. High surface hardness, providing the highest possible polishing and scratch resistance, as well as excellent wettability, contributing to a decrease in the friction coefficient, are the main prerequisites for reducing the wear and long-term survival [21]. Nevertheless, a number of specific problems still limit the wider use of ceramic friction units in hip joint PTA. Those are the development of acoustic phenomena and the likelihood of a liner breach, as well as a small size of the acetabular component [22, 23, 24, 25].

Therefore, the use of ceramic heads in combination with highly cross-linked polyethylene is currently considered the "gold standard" [14]. In particular, in a randomized study by Young-Hoo Kim and Jang-Won Park, who investigated ceramic-on-ceramic joints and friction pairs "ceramics combined with highly cross-linked polyethylene" in contralateral joints in the same patients for a period of 18 years, no obvious advantage of any options studied was found [18]. At the same time, metal heads in combination with liners made from both conventional polyethylene and crosslinked polyethylene have been used in the Russian Federation in most cases for primary hip replacement
[26]. Metal heads are used in various versions, with a ceramic surface (zirconium oxide, titanium nitride), cobalt-chromium alloy and stainless steel. There is no firm data on the comparative effectiveness of their use, but there are theoretical prerequisites for lesser abrasion of polyethylene in combination with the heads made of ceramicized metals and cobaltchromium alloys, due to their greater hardness and scratch resistance compared to the heads made of stainless steel [27].

The clinical case presented is interesting because the patient had implants of the same manufacturer, the same acetabular components, similar polyethylene liners and the same diameter of the friction pairs. Accordingly, in this observation, the influence of the patient factor on the wear process is completely excluded, the effect of the implant is practically minimized, and only the surgical factor remains. The operations were performed by one surgeon with an interval of two years. Therefore, the decisive moment in this case remains the incorrect position of the acetabular component. The malposition of the acetabular component is considered by many authors as a factor that has an adverse impact on the wear process of a polyethylene liner [28]. Cup verticalization is especially unfavorable, but excessive anteversion also disrupts the process of normal load redistribution and leads to marginal loading of the liner [2, 29]. In particular, an experimental study on models performed by N. Kaku et al. (2017) showed that the larger are the values of the tilt and anteversion of the acetabular component, the greater is the stress experienced by the friction pair, which leads to accelerated wear [30]. In our case, there was not only a more vertical position of the cup but also an extremely pronounced anteversion. This malposition led to accelerated wear of friction surfaces and osteolysis developed faster, when compared to the contralateral joint. Probably, the process was significantly accelerated after a breach of the liner and the contact of the head with a metal cup. On the one hand, such a compromised friction leads to the release of metal wear particles, causing metallosis and synovitis, and on the other hand, a breach of the liner could independently become a source of pain due to local irritation of the surrounding tissues. 


\section{CONCLUSION}

The case presented may be considered a very good result of primary arthroplasty, as far as the revision surgery in this young patient was performed only 17 years after. However, in the contralateral joint the implant with the same friction pair has survived for 19 years and at the moment it is still early to decide on its revision. In our opinion, this case is an excellent illustration of the importance of the correct positioning of implant components.

\section{REFERENCES}

1. Nikolaev N.S., Maliuchenko L.I., Preobrazhenskaia E.V., Karpukhin A.S., Iakovlev V.V., Maksimov A.L. Primenenie individualnykh vertluzhnykh komponentov $\mathrm{v}$ endoprotezirovanii tazobedrennogo sustava pri posttravmaticheskom koksartroze [The use of individual acetabular components in the hip arthroplasty for posttraumatic coxarthrosis]. Genij Ortopedii, 2019, vol. 25, no. 2, pp. 207-213. (in Russian) DOI: 10.18019/1028-4427-2019-25-2-207-213.

2. Tian J.L., Sun L., Hu R.Y., Han W., Tian X.B. Correlation of Cup Inclination Angle with Liner Wear for Metal-on-polyethylene in Hip Primary Arthroplasty. Orthop. Surg., 2017, vol. 9, no. 2, pp. 186-190. DOI: 10.1111/os.12337.

3. Shubniakov I.I., Tikhilov R.M., Denisov A.O., Akhmedilov M.A., Chernyi A.Zh., Totoev Z.A., Dzhavadov A.A., Karpukhin A.S., Muraveva Iu.V. Chto izmenilos v strukture revizionnogo endoprotezirovaniia tazobedrennogo sustava v poslednie gody? [What has changed in the structure of the hip arthroplasty in recent years?]. Travmatologiia i Ortopediia Rossii, 2019, vol. 25, no. 4, pp. 9-27. (in Russian) DOI: 10.21823/2311-2905-2019-25-4-9-27.

4. Izmalkov S.N., Bratiichuk A.N., Usov A.K., Galeev F.Sh., Litvinov S.A. Prognozirovanie veroiatnosti revizionnogo endoprotezirovaniia tazobedrennogo sustava s zamenoi vertluzhnogo komponenta $v$ zavisimosti ot vida ego tsementnoi fiksatsii [Prediction of the probability of the hip revision arthroplasty with the replacement of the acetabular component depending on the type of its cement fixation]. Genij Ortopedii, 2019,vol. 25, no. 4, pp. 474-480. (in Russian) DOI: 10.18019/1028-4427-2019-25-4-474-480.

5. Kaminskii A.V., Marchenkova L.O., Pozdniakov A.V. Revizionnoe endoprotezirovanie tazobedrennogo sustava: epidemiologiia, prichiny, faktory riska (obzor zarubezhnoi literatury) [Revision arthroplasty of the hip: epidemiology, causes, risk factors (review of foreign literature)]. Vestnik Travmatologii i Ortopedii im. N.N. Priorova, 2015, no. 2, pp. 83-89. (in Russian)

6. Maksimov A.L. Osobennosti revizionnogo endoprotezirovaniia tazobedrennogo sustava pri asepticheskoi nestabilnosti komponentov (obzor literatury) [Specific characteristics of the hip revision arthroplasty in case of aseptic component instability (review of the literature)]. Uralskii Meditsinskii Zhurnal, 2017, no. 7 (151), pp. 93-100. (in Russian)

7. Kolondaev A.F., Balberkin A.V., Zagorodnii N.V. Polveka ispolzovaniia sverkhvysokomolekuliarnogo polietilena v endoprotezirovanii. Dostizheniia, problemy, perspektivy [Half a century of the use of ultra-high molecular-weight polyethylene in arthroplasty. Achievements, problems, prospects]. Vestnik Travmatologii i Ortopedii im. N.N. Priorova, 2012, no. 4, pp. 85-94. (in Russian)

8. Shubniakov I.I., Tikhilov R.M., Goncharov M.Iu., Karpukhin A.S., Mazurenko A.V., Pliev D.G., Blizniukov V.V. Dostoinstva i nedostatki sovremennykh par treniia endoprotezov tazobedrennogo sustava (obzor inostrannoi literatury) [Advantages and disadvantages of modern friction pairs of the hip implants (review of foreign literature)]. Travmatologiia $i$ Ortopediia Rossii, 2010, no. 3, pp. 147-156. (in Russian)

9. Bloomfield M.R., Erickson J.A., McCarthy J.C., Mont M.A., Mulkey P., Peters C.L., Pivec R., Austin M.S. Hip pain in the young, active patient: surgical strategies. Instr. Course Lect., 2014, vol. 63, pp. 159-176.

10.Sandgren B., Crafoord J., Olivecrona H., Garellick G., Weidenhielm L. Risk factors for periacetabular osteolysis and wear in asymptomatic patients with uncemented total hip arthroplasties. ScientificWorld Journal, 2014, vol. 2014, pp. 905818. DOI: $10.1155 / 2014 / 905818$.

11. Tikhilov R.M., Shubniakov M.I., Boiarov A.A., Denisov A.O., Shubniakov I.I. Vliianie razlichnykh faktorov na tempy iznosa polietilenovogo vkladysha $v$ endoprotezakh tazobedrennogo sustava [The effect of various factors on the rate of wear of a polyethylene liner in the hip implants]. Travmatologiia i Ortopediia Rossii, 2018, vol. 24, no. 1, pp. 18-28. (in Russian) DOI: 10.21823/2311-2905-2018-24-1-18-28.

12.Malahias M.A., De Martino I., Gu A., Baral E., Wright T.M., Sculco P.K. Complete wear-through of a metal-backed acetabular cup in an ambulatory patient. Arthroplast. Today, 2019, vol. 5, no. 4, pp. 394-400. DOI: 10.1016/j.artd.2019.09.008.

13.Broomfield J.A., Malak T.T., Thomas G.E., Palmer A.J., Taylor A., Glyn-Jones S. The Relationship between Polyethylene Wear and Periprosthetic Osteolysis in Total Hip Arthroplasty at 12 Years in a Randomized Controlled Trial Cohort. J. Arthroplasty, 2017, vol. 32, no. 4, pp. 1186-1191. DOI: 10.1016/j.arth.2016.10.037.

14.Carli A., Koch C.N., Esposito C.I., Wright T.M., Padgett D.E. Polyethylene Wear Increases in Liners Articulating With Scratched Oxidized Zirconium Femoral Heads. Clin. Orthop. Relat. Res., 2018, vol. 476, no. 2, pp. 182-192. DOI:10.1007/ s11999.0000000000000040.

15.Tone S., Hasegawa M., Puppulin L., Pezzotti G., Sudo A. Surface modifications and oxidative degradation in MPC-grafted highly cross-linked polyethylene liners retrieved from short-term total hip arthroplasty. Acta Biomater., 2018, vol. 66, pp. 157-165. DOI: 10.1016/j.actbio.2017.11.012.

16.Tikhilov R.M., Shubniakov M.I., Shubniakov I.I., Sivkov V.S., Malygin R.V., Tsybin A.V., Liubchak V.V. Dvigatelnaia aktivnost patsientov molodogo vozrasta posle endoprotezirovaniia tazobedrennogo sustava [The motor activity of young patients after the hip arthroplasty]. Sovremennye Problemy Nauki i Obrazovaniia, 2018, no. 1, pp. 66. (in Russian)

17.Hadley M., Hardaker C., Isaac G., Fisher J. Wear of different materials for total hip replacement under adverse stop-dwell-start in vitro wear simulation conditions. Proc. Inst. Mech. Eng. H, 2018, vol. 232, no. 12, pp. 1261-1270. DOI: 10.1177/0954411918813385.

18.Kim Y.H., Park J.W. Eighteen-Year Follow-Up Study of 2 Alternative Bearing Surfaces Used in Total Hip Arthroplasty in the Same Young Patients. J. Arthroplasty, 2020, vol. 35, no. 3, pp. 824-830. DOI: 10.1016/j.arth.2019.09.051. 
19.Murylev V.Iu., Kavalerskii G.M., Terentev D.I., Rukin A.Ia., Elizarov P.M., Muzychenkov A.V. Piatiletnie rezultaty primeneniia keramicheskikh i keramo-polietilenovykh par treniia pri endoprotezirovanii tazobedrennogo sustava [Five-year results of using ceramic and ceramic-polyethylene friction pairs for the hip arthroplasty]. Travmatologiia i Ortopediia Rossii, 2017, vol. 23, no. 1, pp. 89-97. (in Russian) DOI: 10.21823/2311-2905-2017-23-1-89-97.

20.Turakhodzhaev F.A., Magomedov Kh.M., Kalashnikov S.A., Zagorodnii N.V. Endoprotezirovanie tazobedrennogo sustava primeneniem pary treniia keramika-poperechnosviazannyi polietilen srokom nabliudeniia 10 let [The hip arthroplasty by using ceramics-cross-linked polyethylene friction pair for ten-year follow-up]. Vestnik Rossiiskogo Nauchnogo Tsentra Rentgenoradiologii Minzdrava Rossii, 2016, vol. 16, no. 3, pp. 5. (in Russian)

21.Blakeney W.G., Beaulieu Y., Puliero B., Lavigne M., Roy A., Massé V., Vendittoli P.-A. Excellent results of large-diameter ceramicon-ceramic bearings in total hip arthroplasty: Is Squeaking Related to Head Size. Bone Joint J., 2018, vol. 100-B, no. 11, pp. 14341441. DOI: 10.1302/0301-620X.100B11.BJJ-2018-0532.R1.

22.Goretti C., Polidoro F., Paderni S., Belluati A. Ceramic on ceramic total hip arthroplasty and liner fracture. Two case reports and review of literature. Acta Biomed., 2019, vol. 90, no. 12-S, pp. 192-195. DOI: 10.23750/abm.v90i12-S.8961.

23.Pawar E.D., Yadav A.K., Sharma A., Harsoor A. Ceramic liner fracture in ceramic on ceramic Total hip arthoplasty: A case report. Int. J. Surg. Case Rep., 2019, vol. 65, pp. 242-244. DOI: 10.1016/j.ijscr.2019.10.079.

24.Roffe L., FitzPatrick A.J., Rodgers G.W., Woodfield T.B.F., Hooper G.J. Squeaking in ceramic-on-ceramic hips: No evidence of contribution from the trunnion morse taper. J. Orthop. Res., 2017, vol. 35, no. 8, pp. 1793-1798. DOI: 10.1002/jor.23458.

25.Wu G.L., Zhu W., Zhao Y., Ma Q., Weng X.S. Hip Squeaking after Ceramic-on-ceramic Total Hip Arthroplasty. Chin. Med. J. (Engl), 2016, vol. 129, no. 15, pp. 1861-1866. DOI:10.4103/0366-6999.186654.

26.Shubniakov I.I., Tikhilov R.M., Nikolaev N.S., Grigoricheva L.G., Ovsiankin A.V., Chernyi A.Zh., Drozdova P.V., Denisov A.O., Veber E.V., Kuzmina I.V. Epidemiologiia pervichnogo endoprotezirovaniia tazobedrennogo sustava na osnovanii dannykh registra artroplastiki RNIITO im. R.R. Vredena [Epidemiology of the hip primary arthroplasty based on the data of Arthroplasty Register of Russian Vreden Scientific Research Institute of Traumatology and Orthopaedics]. Travmatologiia i Ortopediia Rossii, 2017, vol. 23, no. 2, pp. 81-101. (in Russian) DOI: 10.21823/2311-2905-2017-23-2-81-101.

27.Tikhilov R.M., Shubniakov I.I., eds. Rukovodstvo po khirurgii tazobedrennogo sustava v 2 t. [Guide to the Hip Surgery. In 2 Vol.]. SPb., RNIITO im. R.R. Vredena, 2014, vol. 1, 368 p. (in Russian)

28.Korduba L.A., Essner A., Pivec R., Lancin P., Mont M.A., Wang A., Delanois R.E. Effect of acetabular cup abduction angle on wear of ultrahigh-molecular-weight polyethylene in hip simulator testing. Am. J. Orthop., 2014, vol. 43, no. 10, pp. 466-471.

29. Kolesnik A.I., Gavriushenko N.S., Bulgakov V.G., Frolov E.B., Fomin L.V. Vliianie ugla inklinatsii na iznos polietilenovykh vkladyshei v eksperimentalnom module endoproteza tazobedrennogo sustava [The influence of the inclination angle on the wear of polyethylene liners in the experimental module of the hip implant]. Vestnik Travmatologii i Ortopedii im. N.N. Priorova, 2016, no. 4, pp. 60-65. (in Russian)

30.Kaku N., Tabata T., Tagomori H., Abe T., Tsumura H. The mechanical effects of cup inclination and anteversion angle on the bearing surface. Eur. J. Orthop. Surg. Traumatol., 2018, vol. 28, no. 1, pp. 65-70. DOI: 10.1007/s00590-017-2025-6.

Received: 10.03 .2020

\section{CInformation about the authors:}

1. Rashid M. Tikhilov, M.D., Ph.D., Professor,

Vreden National Medical Research Center of Traumatology and Orthopedics, Saint Petersburg, Russian Federation

2. Maxim I. Shubnyakov, M.D.,

Vreden National Medical Research Center of Traumatology and Orthopedics, Saint Petersburg, Russian Federation

3. Andrey A. Boyarov, M.D., Ph.D.,

Vreden National Medical Research Center of Traumatology and Orthopedics, Saint Petersburg, Russian Federation

4. A. Riahi, M.D.,

Vreden National Medical Research Center of Traumatology and Orthopedics, Saint Petersburg, Russian Federation

5. Igor I. Shubnyakov, M.D., Ph.D.,

Vreden National Medical Research Center of Traumatology and Orthopedics, Saint Petersburg, Russian Federation, Email: shubnyakov@mail.ru 